\title{
The Separate Journeys of Two Parallel Animation Histories: An Analysis of the Differences in Distribution of Animations Made for Film and for Television in the Netherlands Between 1970-1989
}

\begin{abstract}
In the Netherlands, television animation developed differently from film animation. Between 1970 and 1989 film animators barely had government support, which made them unite to promote and distribute their work internationally. Television did have governmental support, and all broadcasting companies were obligated to have their programmes designed by the NOS, a facility department with employed designers and animators. By examining the journey these two animation traditions undertook throug the distribution channels of film, television, the $16 \mathrm{~mm}$ circuit, festival screening and the museum, we see both disciplines develop and flourish in their own way, while rarely having any overlap. It becomes clear that not only the lack of financial support in film, but also the differences in length and the notion among the Dutch public that animation is for children are reasons for the differences in distribution, until they are finally exhibited side by side at the museum.
\end{abstract}

\section{Keywords}

animation; distribution; film; television; illustration

Dutch animation developed differently from that of other countries. Unlike countries such as the United States, the Netherlands' film industry was fairly small, which meant that animation did not naturally develop within it. In fact, Dutch animation for film and for television developed separately. It first emerged as a new discipline following the growth in demand for cinema commercials - animation studios were founded that made commercials for large Dutch brands. This studio system also made it 
possible to make independent films. This changed around 1970 when individual animators arrived on the Dutch animation scene.

Meanwhile, the situation in Dutch television was completely different. The facility department of the NTS/NOS was responsible for all television facilities and for all broadcasting associations. The department contained graphic designers, illustrators and animators who designed everything that Dutch television programmes needed. There was hardly any overlap between animation for film and for television: with a few exceptions, film animators did not make animations for television and vice versa. This raises the interesting question of why these two animation traditions did not overlap.

To answer this question, this article focuses on the historical developments in the distribution of Dutch animation for both adults and children in film and television, focusing on the period between 1970-1989. This is a particularly suitable period to study because in these 20 years, Dutch film animation developed from mainly commercial to strongly independent, and in Dutch television, animation was developed from scratch. The article examines five distribution channels that are historically important for Dutch film animation, television animation or both: the cinema, television, the $16 \mathrm{~mm}$ circuit, festival screening and museum exhibitions. Animated commercials are not discussed in this article, as this is such a different application of animation that it raises completely different questions related to funding and distribution.

By using comparative methods, not only does the article clearly distinguish film and television animation and their distribution histories, but it also provides insights into the factors that shaped these two separate animation traditions; for example, one of the key factors is governmental support. Whereas film animators only occasionally had support from the Dutch government until the beginning of the 1970s, and subsequent to this such support remained insufficient, TV animators had a solid income while working at the NOS, financed by the government. ${ }^{1}$ This meant that film animators had to be creative to finance their work, whereas the television animators, even though they worked on assignments, had more freedom to make what they wanted. Film animations were mostly distributed abroad, whereas television animations very rarely travelled further than Dutch television sets. By comparing the distribution histories of these two separate animation traditions, a deeper understanding emerges of the Dutch animation history and of how these two traditions found their own ways to satisfy their conditions of existence. 


\section{From pioneers to studio period: Dutch animation before 1970}

All over Europe, the United States and Russia, animations were made quite soon after the medium of film was invented. In fact, certain forms of animation existed long before 1895, when the Brothers Lumière invented this principle of recording and projecting photographic images in sequence to create the illusion of movement. ${ }^{2}$ Flipbooks and the phenakistoscope - a quick rotating carrousel with successive drawings - are both presumed to have originated around $1850 .^{3}$ These can be considered early forms of animation, because they sequence images at a fast pace, thereby creating an optical illusion of movement. There is an important difference between live action film and animation: both consist of usually 24 or 25 frames per second, but in live action film these frames are recorded automatically while the scene unfolds in front of the camera, whereas animation is recorded frame by frame (stop-motion), and in between frames, the scene is altered manually (this is different from computer animation, which is not discussed in this article.) Animation is a very time-consuming practice and often requires considerable amounts of material, such as drawings, puppets or clay, which therefore also makes it expensive. ${ }^{4}$ Animation researcher Mette Peters sees animation as a crossover between film production and visual art practice. ${ }^{5}$ This is one of the reasons why animation is hard to review or research in the same manner as live action film.

In the United States, animation was part of the Hollywood industry, meaning that animated shorts and features were created at an early stage. In the Netherlands, however, animation developed very differently and at a much slower pace. Ton Gloudemans divides Dutch animation history into three periods: the pioneers (1920-1934), the studios (1934-1970) and the individualists (1970-now). ${ }^{6}$ This studio period began when the demand for cinema commercials grew. In 1934, Dutch electronics company Philips asked George Pál, a Hungarian animator who worked at the Trickfilmabteilung of the UFA Filmstudio in Berlin, to come to the Netherlands to make animated commercials. ${ }^{7}$ Pál made Vaudeville-like puppet animations such as Het Aetherschip (1934) and The Sleeping Beauty (1938). ${ }^{8}$ Between 1934 and the start of the Second World War in 1939, at which point he fled to the United States, Pál built up a large studio. ${ }^{9}$ Joop Geesink, who began his career as a set designer, hired at least six of the animators that were trained by Pál, among whom were Joszef Misik and Frans Hendrix, and started his successful studio Dollywood. ${ }^{10}$ Geesink himself did not make any animations: he devised the ideas and let the studio work on them while he continued to find new clients and assignments. ${ }^{11}$ This was a successful system: Geesink had many British and German clients next to his commercials 
for Dutch cinemas, and many of these commercials were translated into 25 languages, so that they could be distributed internationally. ${ }^{12}$ In 1967, when the Netherlands allowed commercials on television for the first time, he made 12 commercials of the 38 in total that the STER (Foundation for Ether Advertisement) began with. ${ }^{13}$ At the end of the 1960s, the company started to fall behind, making it necessary to downsize. Toonder Studio's took over Dollywood, which made the Loeki items between STER commercials from 1972 onwards. ${ }^{14}$ A new generation had taken over, which Geesink grudgingly admits: ‘(..)you say bankrupt, but you are suddenly completely done. And I am too much of a realist not to realise that I had it difficult, yes... And my age, and that young generation. But abroad I was still Joop Geesink, and stil am!'15

Toonder Studio's, founded by Marten Toonder, was by that time an accomplished studio specialised in drawn animation. Toonder was a pioneer in newspaper comics who had his first big success with his comic Tom Poes, which he made for De Telegraaf in $1941 .{ }^{16}$ He hired Wim Lensen as an assistant and gradually a studio system emerged. ${ }^{17}$ The comic became a big success when in the

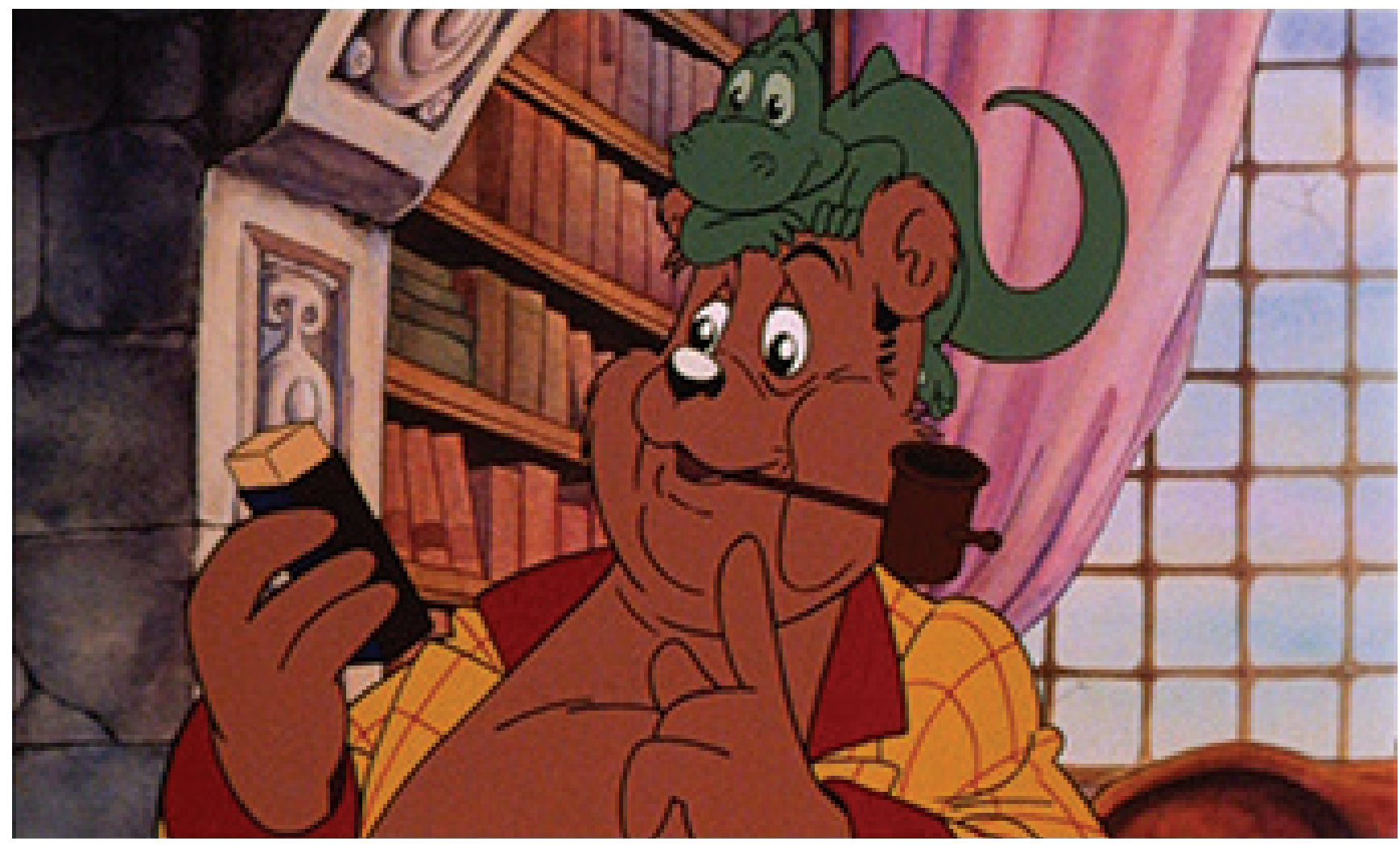

Figure 1. Still from Als je begrijpt wat ik bedoel (Marten Toonder 1983). Source: IMDB (https://www.imdb.com/title/tt0188404/). 
third story of Tom Poes the eccentric bear Olivier B. Bommel made his entrance. During wartime, Toonder made some animated Tom Poes films, among which was Tom Puss und das Geheimnis der Grotte, with German company Degeto. ${ }^{18}$ After the war, Toonder made three films for the experimental television broadcasts by Philips: Floepedorus (1949), Plucky Panda's Penny (1949) and Het monster van Loch-Ness (1950). ${ }^{19}$ These animations were much more simplified than those he made during the war: for the most part they consisted of cut out animation, with some cartoon elements that were more extensively animated. ${ }^{20}$ This reflects the fact that animation was difficult to achieve for television. Toonder Studio's also made independent films and many client films for among others Philips, Albert Heijn and Shell, as well as several Bommel cartoons for the American market. ${ }^{21}$ Because of these commissions and the highly popular Olivier B. Bommel comic, Toonder was able to finance many independent animated shorts.

\section{Film animation - distribution between 1970 and 1989}

As mentioned above, Joop Geesink's puppet animation studio ceased to exist in 1970, when young individualist animators took over the animation sector. Marten Toonder continued, partly because of the considerable success of his Bommel newspaper comics. Some of the studio's client films, such as 300.000.000 (ILO, 1973) and Getekende mensen (Stichting Breek, 1984) achieved international success and received awards. ${ }^{22}$ In 1983, Toonder's greatest dream was realised: he was able to make an animated feature film. This became Als je begrijpt wat ik bedoel, a movie about Bommel and Tom Poes, and the first animated feature produced in the Netherlands. ${ }^{23}$ In comparison, the first animated feature film in the United States, Snow White and the Seven Dwarfs, was released 47 years prior in 1936.

The individual animators that took over the animation sector were able to do so because of a government decision to encourage animators to make films in their own style. ${ }^{24}$ This support was necessary as the Dutch government had only occasionally funded animation prior to this. In the Netherlands, film was already a smaller medium than in other countries: Karel Dibbets mentions that the Netherlands had fewer cinemagoers, as well as fewer cinemas, than surrounding countries. ${ }^{25}$ As an explanation he mentions the pillarisation of the Dutch society: Dutch cinemas were not pillarised. Whether or not this is the reason, it did make it harder for Dutch filmmakers, and therefore animators to an even greater extent, to earn back their investments. 


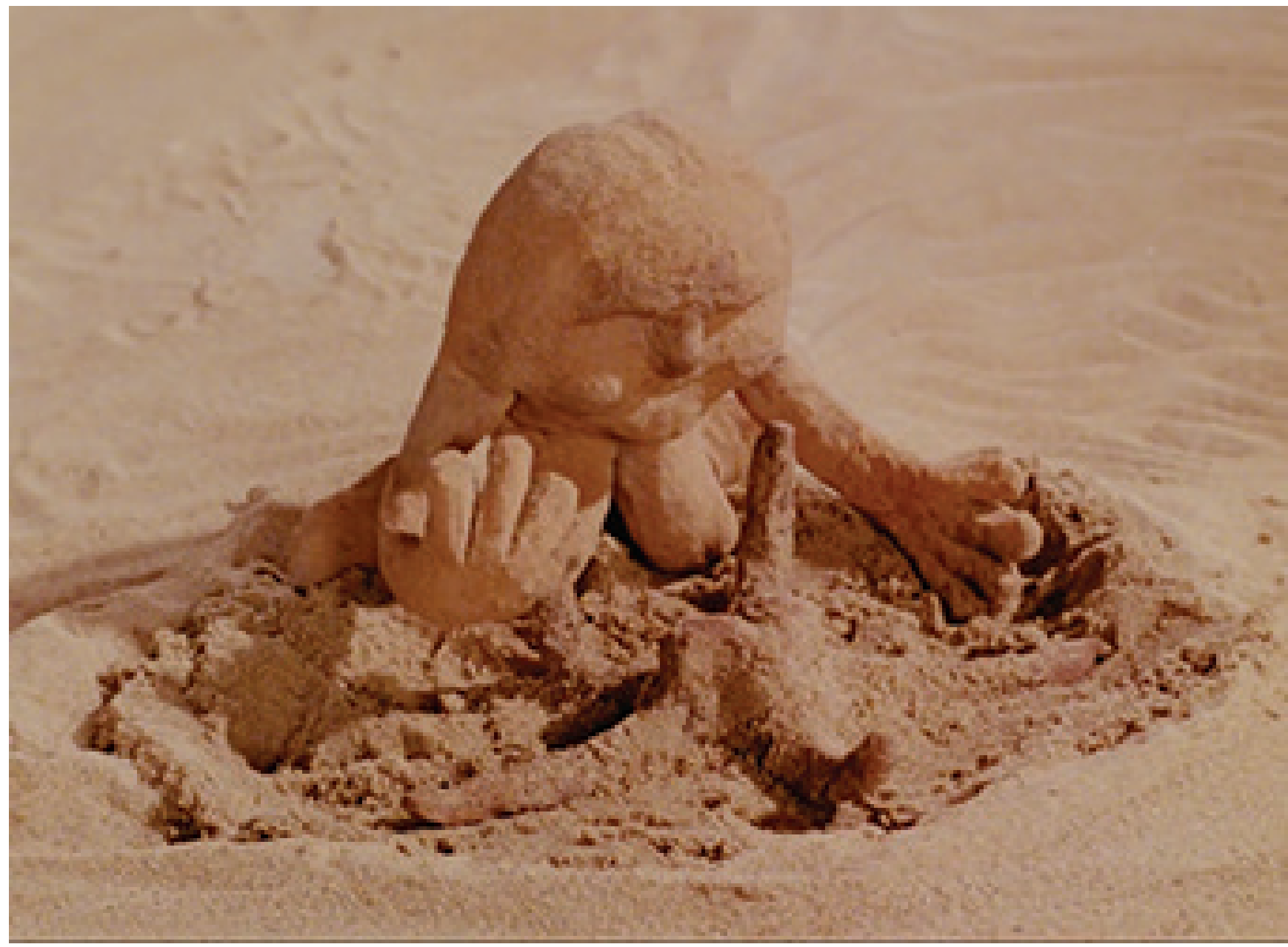

Figure 2. Still from Het Zandkasteel (Co Hoedeman 1978). Source: YouTube, uploaded by the Canadian National Film Board (https://www.youtube.com/watch?v=hzvqmoPu2H4).

Thanks to the financial support at the start of the 1970s, animators such as Gerrit van Dijk, Paul Driessen, Monique Renault and Co Hoedeman were able to make independent short films and did not have to rely on commercial work or a studio system as Pál, Geesink and Toonder had done previously. This new generation of animators only made short films, and most of them drew or painted them frame by frame, each in their own specific style. Van Dijk and Renault, for instance, used drawings and sometimes painted, and more than once used character transformations to convey a message of social criticism. The animations of these independent filmmakers were difficult to distribute in Dutch cinemas, as around 1970, feature films in Dutch cinemas began to be less frequently preceded by short films. The few times cinemas did need shorts, they also had no reason to buy Dutch ones, as Disney 
gave them away for free when cinemas purchased an animated Disney feature, so the cinemas already had sufficient numbers of shorts in their collection to screen before the main film. ${ }^{26}$ Television was not an ideal distribution option either, as the lengths of animated shorts varied, which made it difficult to fit them in the usually very tight programming schedules, meaning film animations were rarely shown on television. ${ }^{27}$ The $16 \mathrm{~mm}$ circuit was growing however, due to an increase in interest from universities, schools and museums, but this would always remain a very small market. ${ }^{28}$ Cilia van Dijk, van Dijk's wife, collected animated shorts and had around 150 films in 1983, which she rented out on $16 \mathrm{~mm} .{ }^{29}$ Within five years she had rented out her films 1500 times to a small but interested audience. ${ }^{30}$

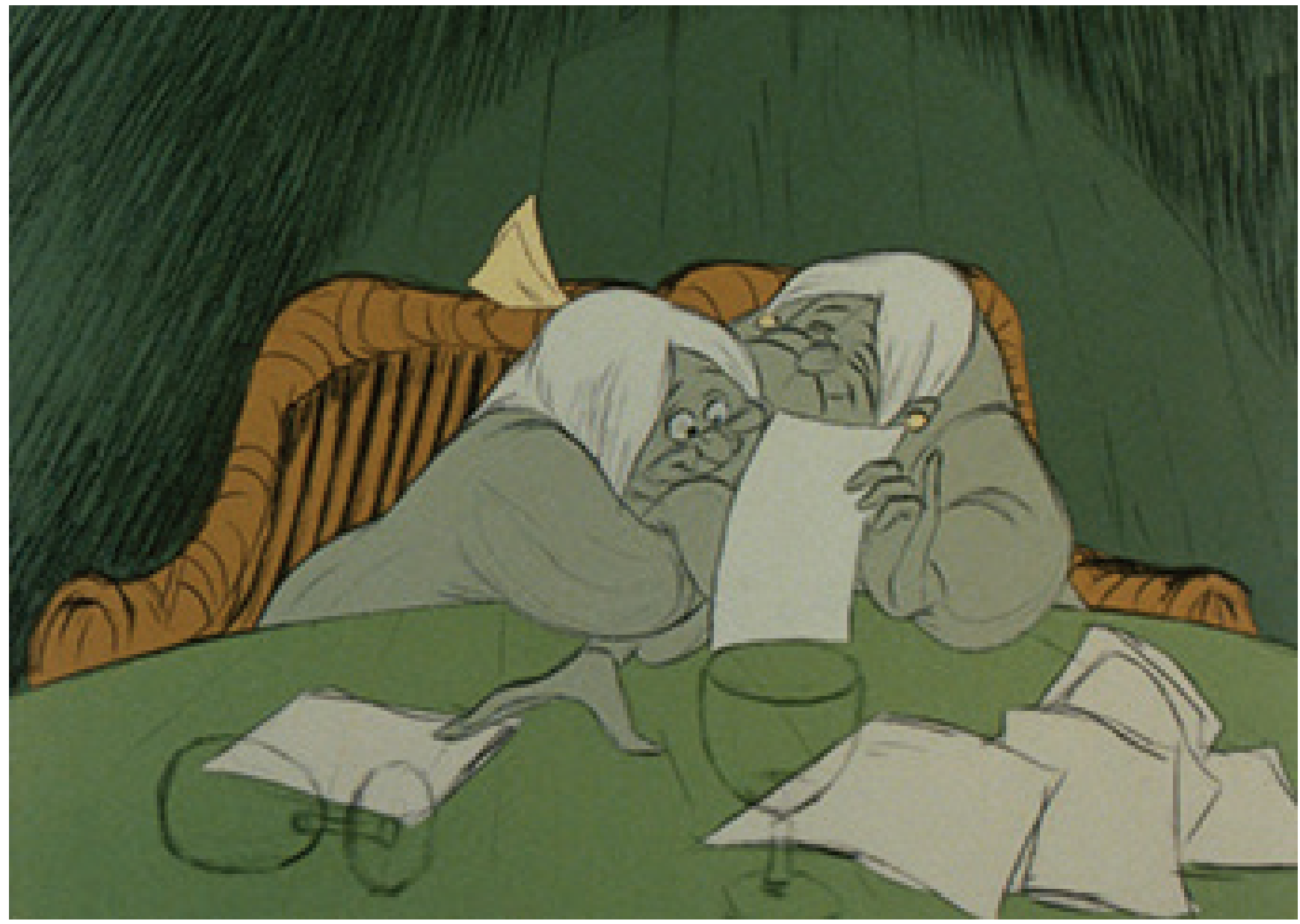

Figure 3. Still from Anna en Bella (Børge Ring 1986). Source: Eye Film Institute (https://www.eyefilm.nl/film/films-van-børge-ring). 
The problems in distribution of Dutch animation, and the fact that government support was insufficiently large to support all animators, led in 1973 to the establishment of an association of animators called Vereniging Holland Animation, which had approximately 150-200 members. ${ }^{31}$ This association united animators and ensured their work was screened at international film and animation festivals such as Annecy, Ottawa and Zagreb, where they were well received. ${ }^{32}$ From 1976 onwards, chairman Nico Crama built a stable position for Dutch animation at the international festivals, which accelerated when Crama set up the foundation Holland Animation next to the association, tasked with focusing on the continuous distribution of animation. ${ }^{33}$ Although not even half of the Dutch animations received financial support in the Netherlands, in ten years of Holland Animation there have been over 200 animations made that have seen almost all relevant festivals in the Netherlands and abroad. ${ }^{34}$ The Netherlands has had its own animation festival since 1985, called the Holland Animation Film Festival (HAFF). ${ }^{35}$ Festival screening can be seen as a fourth distribution channel, as it reaches a new public.

The animators who appeared at these festivals were a very diverse group. From the Toonder studio came Harold Mack, an Englishman who started his own studio and taught animators such as Rupert van der Linden, Bill Karstens and Paul Heijnneman. This was sometimes spoken of as the Mack School by Holland Animation members. Other animators who started at Toonder Studios included three Danish animators - Børge Ring, Bjorn Frank Jensen and Per Lygum - who were all highly skilled. ${ }^{36}$ All three started working for themselves and had success. ${ }^{37}$ However, outside the studios, animators such as the aforementioned Gerrit van Dijk, Co Hoedeman, Monique Renault and Paul Driessen emerged in the field. All these animators had very different styles and techniques but shared a common trait that their works were very visual with little to no dialogue, and many of them made films for adults about societal issues. ${ }^{38}$ The international success that Dutch documentary makers such as Bert Haanstra and Charles Huguenot van der Linden enjoyed in the 1950s (Haanstra received an Oscar for Glas, and van der Linden received one for Die Kleine Wereld) was now being experienced by Dutch short animation: Hoedeman received an Academy Award for Het Zandkasteel in 1978, and Ring received one in 1986 for Anna en Bella. ${ }^{39}$ At the same time, the Dutch public barely knew of them because of the limited distribution possibilities in The Netherlands: the animators received $90 \%$ of their income from abroad thanks to Holland Animation. ${ }^{40}$ Crama explains that the large film festivals, such as Berlin and Cannes, emphasised live action features, so animation, and 
especially animated shorts, were shown as sideshows, although they often had separate prizes for them. However, the main attention went on the features and their stars. Therefore, Holland Animation focused more on festivals such as Oberhausen, a festival for short films, and the animation festivals in Ottawa, Annecy and Zagreb. Here, Dutch animated shorts were much more appreciated and attracted the right press and distributors. ${ }^{41}$

Dutch Animation turned out to be ideal for distribution abroad, as the animators had a visual language rather than one of dialogue, so their animations spoke an international language. In addition, the animations were often timeless: because of the long process of making an animated film, however short its duration, these films rarely reacted to news or actualities (although they could be very political or raise societal issues). ${ }^{42}$ This made it possible to show them for a longer period of time, which was an interesting proposition for distributors. The foreign television market in particular was lucrative: between 1973 and 1983, Dutch animated shorts were shown on television in 25 countries, and the costs of the production of the animations could be earned back, especially when Holland Animation managed to find a distributor for several animated shorts at once, or several distribution channels in a country at once. The role of Holland Animation was to identify these distribution possibilities but also to manage the screening rights. Cinema, as well as television distributors, often tried to gain the exclusive rights to make it impossible for others in the same country to also screen the film, but for the animators united in Holland Animation, the best deal of course was being able to distribute through all available channels, mainly cinema, television and the $16 \mathrm{~mm}$ circuit. This worked particularly well in the United States, where cable channels and Pay-TV aired a considerable amount of animation and the $16 \mathrm{~mm}$ circuit was quite large. This included screenings at universities, cities and museums, which often liked to screen compilations of 'The Best of Zagreb, Ottawa en Annecy'. ${ }^{43}$ Animation was rarely profitable, because costs of approximately 10,000 guilders a minute (in 1983) had to be earned back first. ${ }^{44}$ Especially with the small budget that the government made available - of the 30 million guilders that the Dutch Film Fund paid out, approximately 1.4 million went to animation, which is not even $5 \% .{ }^{45}$ However, with the help of Holland Animation, it was often still possible to earn the investments back. ${ }^{46}$

In comparison to live action film, Dutch animation performed extremely well at international film festivals in the 1980s: of the top 20 Dutch films screened at international film festivals between 1980 and 1989, six were animations, which is particularly impressive if you consider that not even $5 \%$ of the national budget went to animation. ${ }^{47}$ From these screening possibilities at 


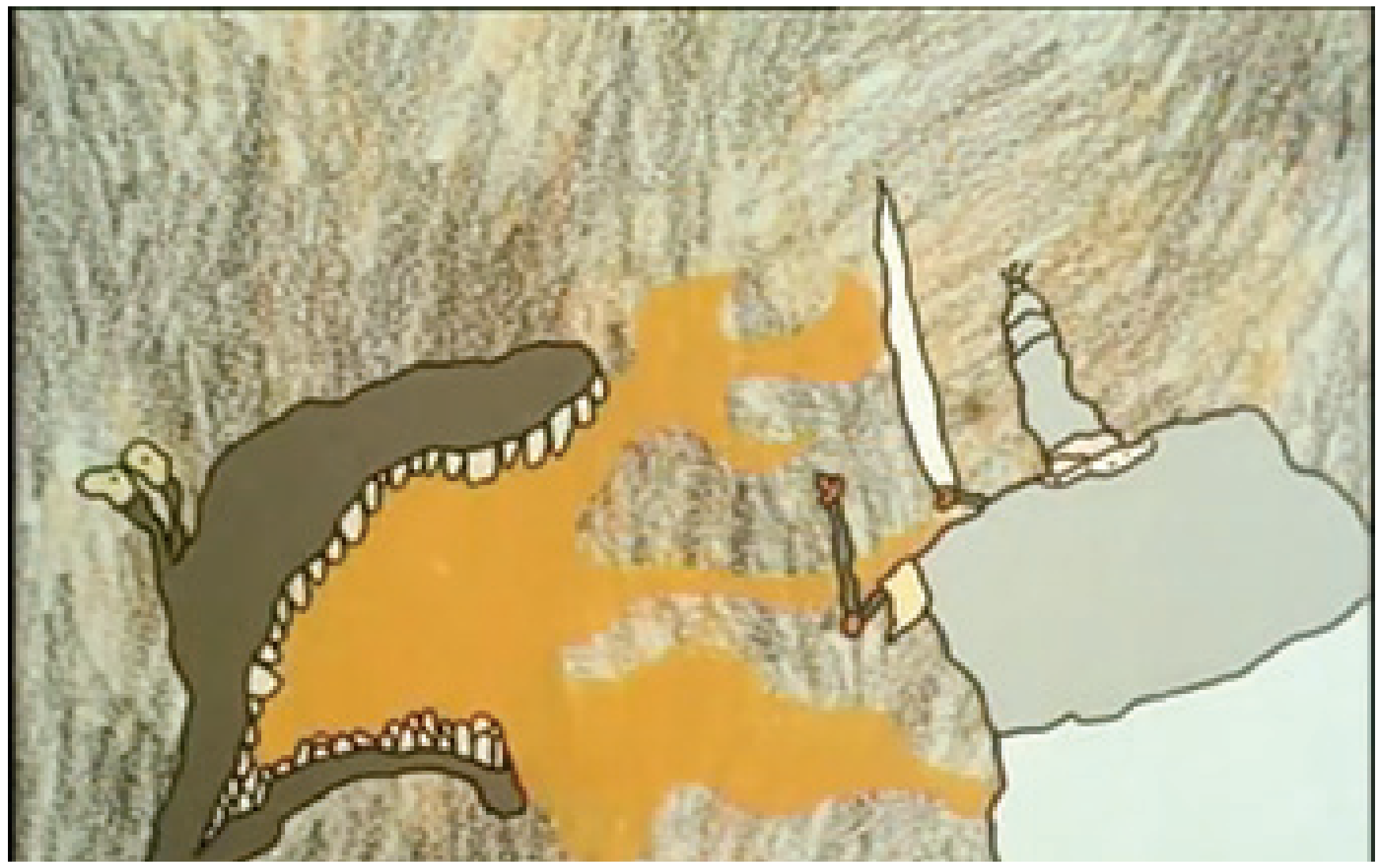

Figure 4. Still from Oh what a knight (Paul Driessen 1982). Source: YouTube, uploaded by Witusss (https://www. youtube.com/watch?v=87OUak4OSSY).

festivals came recognition, from peers as well as from the boards and juries; consequently, Dutch animators received numerous prizes. The Academy Awards for Hoedeman's Zandkasteel and Ring's Anna en Bella have already been mentioned, but Ring also had an Oscar nomination for Oh My Darling in 1979, which went on to receive the jury prize for best short film at the Cannes Film Festival that year. ${ }^{48}$ Gerrit van Dijk and Monique Renault won a Golden Bear for Pas à Deux in 1989 and van Dijk also won a Gouden Kalf for A Good Turn Daily in 1984, to name just a few of the wins at large film festivals. At the specialised festivals they had even more successes: at Annecy 1977, for example, David by Paul Driessen and Het Zandkasteel by Co Hoedeman both won the Grand Prix for best animated short, ${ }^{49}$ and in 1982 Oh what a knight by Driessen won the first prize at Ottawa in the category Very Short Films. ${ }^{50}$ The successes that Dutch animation had at international festivals helped the animators to receive funding for new projects. Issues of the Orgaan van de Nationale 


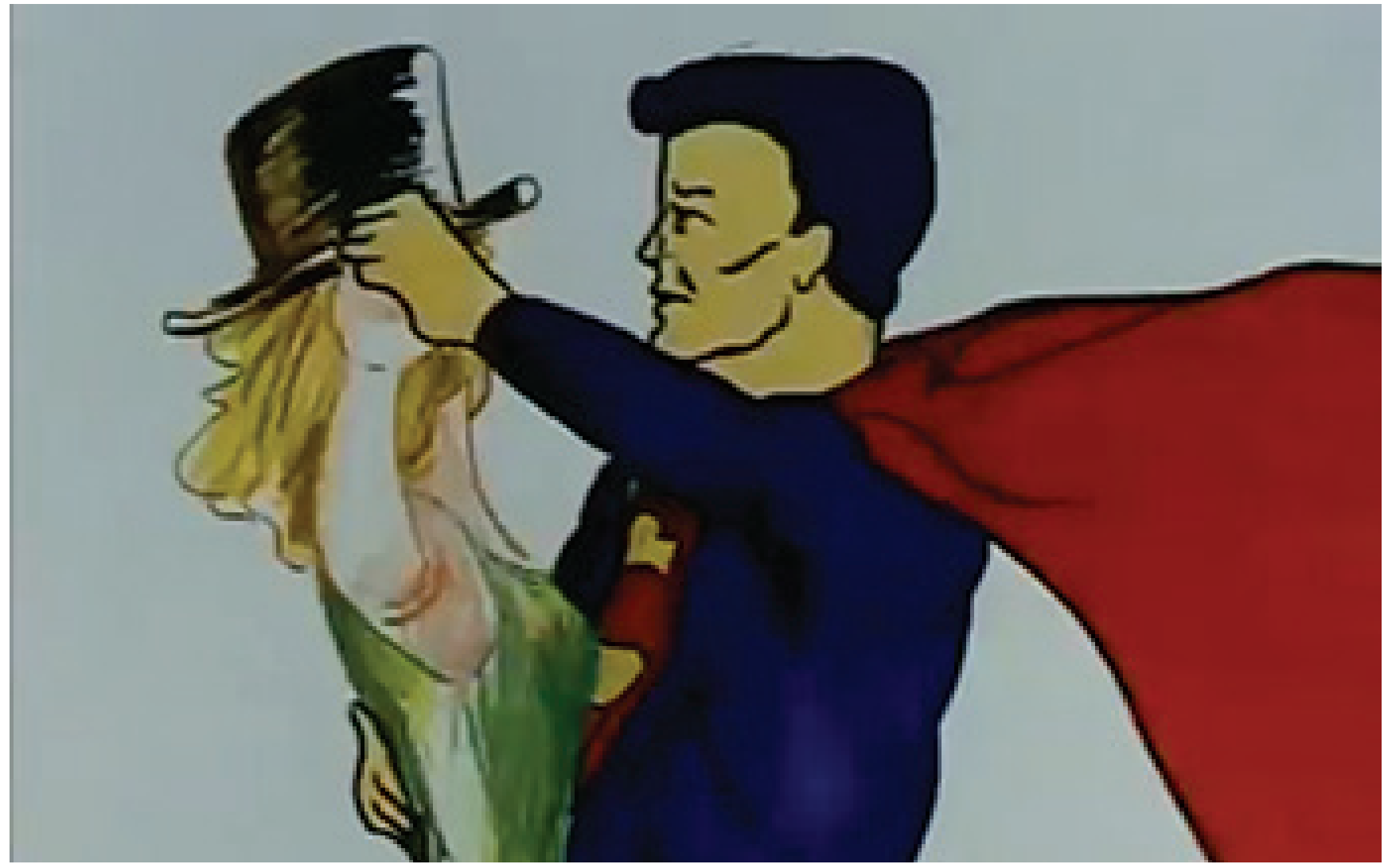

Figure 5. Still from Pas a deux (Gerrit van Dijk, Monique Renault 1988). Source: YouTube, uploaded by Gerrit van Dijk (https://www.youtube.com/watch?v=ZN4TBn9C1Zk).

Bioscoop Bond often mention new governmental funding for films, along with references to Driessen and Renault. ${ }^{51}$

In the meantime in the Netherlands, the media were largely unaware of the quality and success of Dutch animation, so they barely reported on Hoedeman's Oscar win and Ring's Oscar nomination. Even Hans Nassenstein's Nog Eens, which received a Dutch Gouden Kalf in 1982, received hardly any media attention. The Dutch public did not know about Dutch animation and thought that it was for children. This was because Dutch animations, which were mostly made for adults, were rarely screened in the Netherlands, with the result that the Dutch public was much more familiar with the Disney cartoons. ${ }^{52} \mathrm{~A}$ few notable exhibitions helped change the perception of animation in the Netherlands somewhat: in 1974 the Stedelijk Museum Amsterdam staged the exhibition Beeldje voor Beeldje about Dutch animation. The exhibition showed how Toonder and Geesink gave Dutch animation its allure, but explained how the individual animators in Holland Animation were the first 
to push towards an independent art form. ${ }^{53}$ In 1977, the Haags Gemeentemuseum followed with an exhibition on six designers from The Hague, among whom was Driessen. ${ }^{54}$ Furthermore, to celebrate 10 years of Holland Animation, in 1983 there were several exhibitions, a symposium, screenings of new animations and other events throughout the country in an attempt to establish a connection with the Dutch public. ${ }^{55}$ Through these exhibitions in museums, a new type of public - that of the museumgoer - was introduced to Dutch animation, so exhibitions here can be seen as the fifth distribution channel. However, by 1988, the large European public still knew more American and Japanese animations than European ones. Therefore, the European Association of Animation Film (EAAF) was established to make the distribution and coproduction of European animation easier and to fund new talent. Holland Animation represented the Netherlands in this European cooperation. ${ }^{56}$

The lack of government support for Dutch animation in the 1970s and 1980s unintentionally began a very uncommon distribution route: Dutch animations made a large, international detour before getting more publicity in the Netherlands. They were rarely shown in Dutch cinemas because they were short, and cinemas already had enough shorts. They were also rarely shown on Dutch television because they varied too much in length, making programming difficult. In the Netherlands, the $16 \mathrm{~mm}$ circuit was the most profitable format, reaching a small but interested public. It was through uniting with Holland Animation and screening at international specialised festivals, from where distributors in other European countries and the United States continued the distribution in their own countries, that the Dutch animators were able to earn their investments back and reach a large public. Through the winnings at these festivals, animators earned more recognition by the Dutch government, leading to more funding for new projects. The successes abroad also led to several exhibitions in Dutch museums, where a larger public of museumgoers was introduced to the work of previously discussed animators such as Ring, Driessen, van Dijk and Renault.

\section{Television animation - distribution between 1970-1989}

Dutch television animation developed very differently from Dutch animated film. Whereas in Dutch animated film the lack of government funding is constantly evident, Dutch television did enjoy government support: from its beginning in 1951 to the privatisation of the facility department NTS/ NOS in 1988, Dutch television was funded partly by the government and partly by owners of radio 
and/or television sets, and after 1967 also by the income from STER commercials. ${ }^{57}$ There were several main broadcasting associations that represented the main pillars in Dutch society: the catholic KRO, protestant NCRV, socialist VARA and liberal AVRO. There were several other broadcasting associations (and more would follow), and they all had a percentage of the total airing time in accordance with the amount of members they had and how large the group of people was that they represented in society. All broadcasting associations received a budget for the designs of their logos and programmes, from sets and leaders to animation, and they were obligated to spend that budget on the NTS/NOS, a facility department which employed set designers, graphic designers, illustrators and animators. The illustrators made illustrations for television programmes: drawings recorded in live action. Some of these illustrators specialised in stop-motion animation during their career. Most of the animated television programmes until 1988 that were made in the Netherlands were made by designers with a solid income, who worked for the Graphic Design department of the NTS/NOS for their whole career. ${ }^{58}$

There were seven designers at the Graphic Design department of the NTS who specialised in illustrated and/or animated programmes: Hans de Cocq, Henk Vermolen, Jos van Grieken, Johan Volkerijk, Ton Holst, Arie Teunissen and Monaa van Vlijmen. However, until 1970 they rarely made animations. There are two reasons for this: firstly, the time restrictions that television brought made it difficult to produce large amounts of animation with so few people. Therefore, many series and programmes on Dutch television were illustrated instead of animated. The first illustrated television programme that we know of is Telemimiek (AVRO), broadcast on $2^{\text {nd }}$ November 1951.59 The show featured Eppo Doeve, an illustrator who was very well known for, among other things, his newspaper cartoons and book illustrations. Doeve was also known for his ability to draw very quickly, so in Telemimiek, his role was to draw certain situations on paper, live in the studio, which people then had to guess. ${ }^{60}$ Doeve did this on a freelance basis, which was more common in the early years of television, and he illustrated for several more programmes subsequently. Illustration could either be done live in the studio, as Doeve did, or done beforehand, so that the drawings could be shown in front of the camera, which eventually became the convention when television was taped instead of aired live. An example of this is Woord voor Woord: a programme by CVK/IKOR/ RKK that aired from 1965 to 1976. The narrator Aart Staartjes had a fresh way of telling biblical stories, and he was shown on screen interspersed with illustrations by Bert Bouman, Friso Henstra and Peter Vos. This programme worked so well that a children's Bible was made by the same title, 


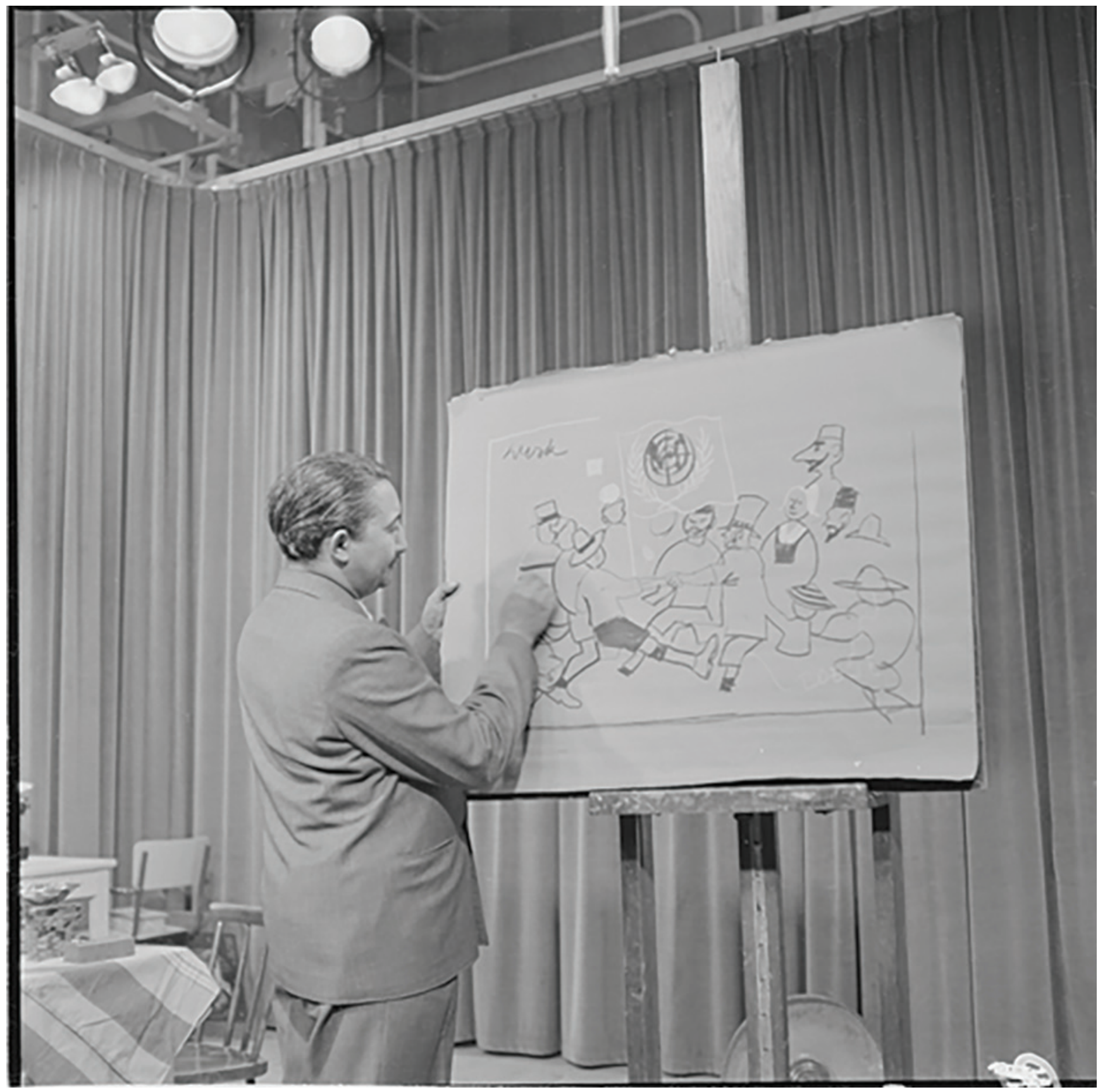

Figure 6. Behind the scenes photo of Telemimiek (Eppo Doeve AVRO 1951). Source: Netherlands Institute for Sound and Vision.

illustrated by Bouman. ${ }^{61}$ The second reason for the lack of complete animated series in Dutch television is that the broadcasting companies were more interested in purchasing existing American and Japanese animated series, a point discussed later. 
Before 1970, the illustrators/animators of the NTS made more graphic designs than illustrations, but they also illustrated programmes, among which were Woord voor Woord (CVK/IKOR/ RKK), Uit Oma's Kabinet (NCRV, 1962, Johan Volkerijk and others) and Circus Kierekiet (KRO, 1967, Ton Holst). Gradually during this period we can observe that some of the illustrations start to have moving elements. Most of the time, these movements are done by moving slits or invisible wire off screen to make parts of the drawing move, similar to a movable book. One example is In die dagen (CVK/IKOR/RKK, 1967), illustrated by Noni Lichtveld. Lichtveld used numerous slides and layers to give the programme movement and depth, and because of this the programme is quite dynamic. This is not yet animation, as these drawings were not made with the stop-motion technique but recorded in live action. The fact that Dutch television programmes were often illustrated instead of animated seems to be unique internationally. The work of the Graphic Design department of the NTS was featured in several exhibitions in the 1960s, among which was Europese Telegrafiek in 1967. Comparing the Dutch designs with those of among others England and Australia, Rolf Mager of the journal Ariadne notes that England and Australia are much more developed in terms of technical facilities but that the 'tv-graphics' by the NTS are still artistic despite the limited means. ${ }^{62}$ It should be noted here that as the illustrators also made graphic designs, for instance opening titles for television programmes, the terminology in the 1960s is also very general: Mager speaks of 'tv-graphics', which in his definition means everything from graphic design to illustration and animation.

In 1969, the NTS and the NRU (the neutral radio organ that addressed programming issues among other things) fused into the NOS (Nederlandse Omroep Stichting), which provided all programme facilities for both radio and television. ${ }^{63}$ The illustrators who worked for the NTS were by now used to working for television and had developed their own style, and in 1971 the Graphic Design department as a whole received the Frans Duwaer Prize for their typographical work. The committee applauded the department for their ability to deliver outstanding work within "too short a time range and under too much strain", and called their work contemporary and original, stating: "Especially where the designer is involved in the development of the visualisation from the very start, he often comes to astounding results." 64

Illustrator Henk Vermolen mentions that the Graphic Design Department was used to their luxury position: directors were obligated to make use of their work, which meant that the designers did not have to pitch it or make themselves known to clients or the public. ${ }^{65}$ The working relationship 


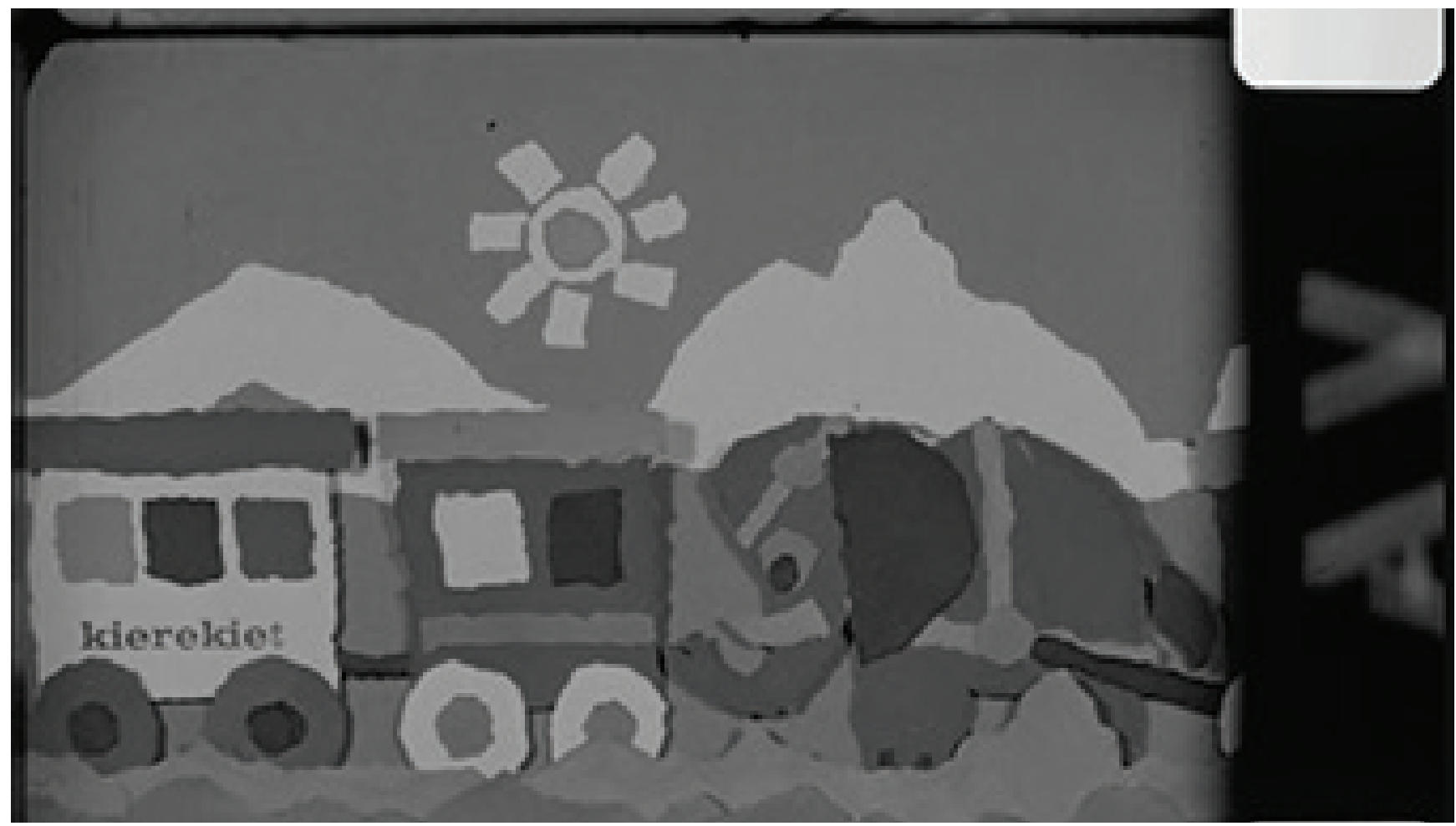

Figure 7. Still from Circus Kierekiet (Ton Holst KRO 1967). Source: Netherlands Institute for Sound and Vision.

between directors and designers was good as well: most illustrators were happy that the directors trusted them enough to give them the freedom to interpret the assignments how they wanted. ${ }^{66}$ Directors were well versed in the qualities of the different illustrators, and they had their favourites ${ }^{67}$ One programme in particular provided considerable work for the illustrators: Sesamstraat: the Dutch version of Sesame Street. The first conversations by the programme council go back as far as 1972, and in 1976 it aired with 50\% American material and 50\% new material per episode. ${ }^{68}$ This program became the best-known children's programme in the Netherlands, as well as the longest running children's programme in Dutch history. The demand for illustrations for Sesamstraat was so large that every illustrator worked for this programme on a regular basis. ${ }^{69}$ These assignments varied from fairy tales to poems, and from songs to recurring stories about a certain character. The illustrators always liked giving shape to these items, as the quality of the scripts was always high, and they gave the illustrators room to interpret them in their own manner. ${ }^{70}$

At the end of the 1960s, the first subtly animated leaders emerged, which were mostly typographic, for instance with letters that switch places. In the beginning of the 1970s, the first 


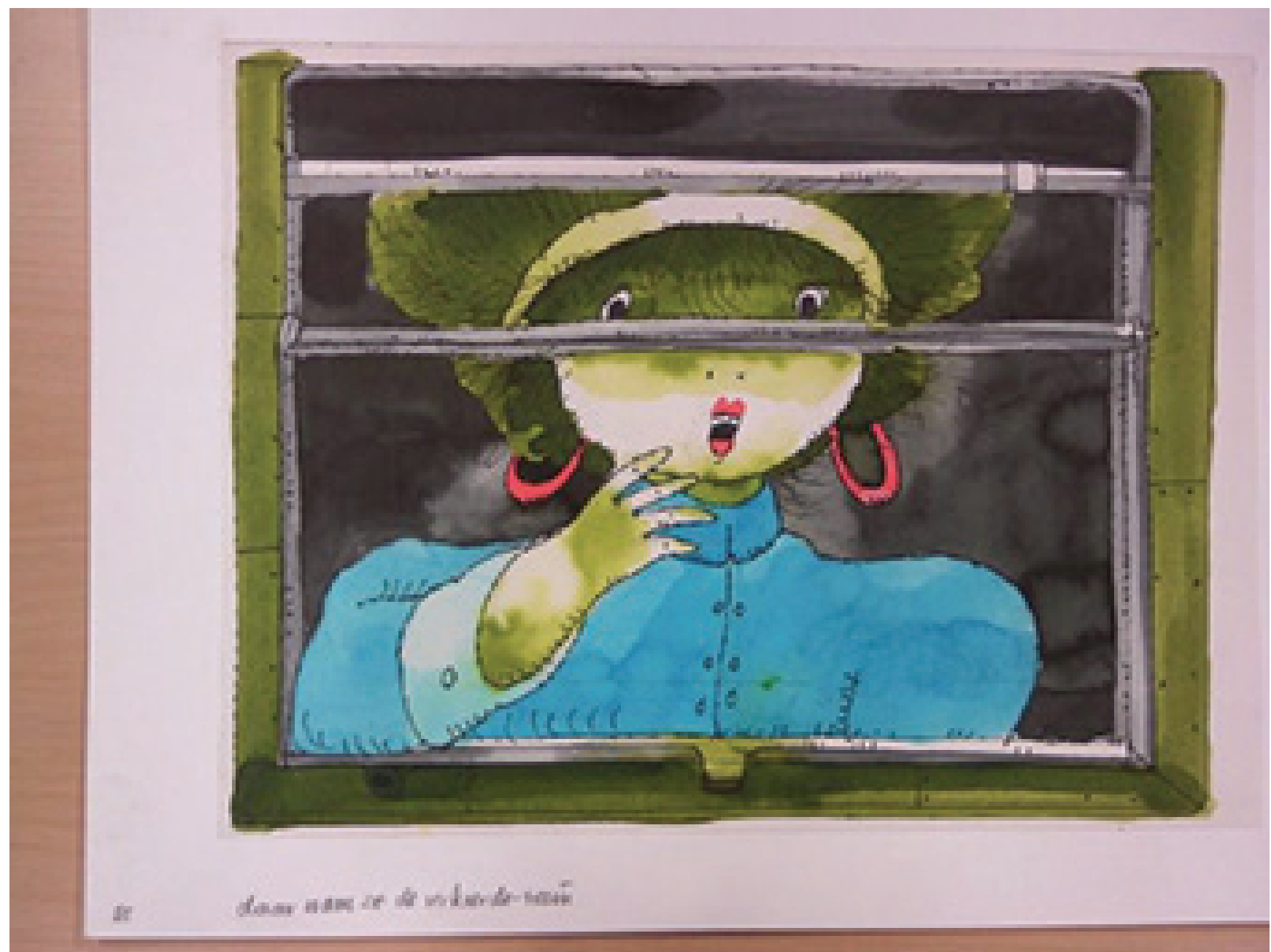

Figure 8. Illustration for 'Waar is Annemiek gebleven' (Henk Vermolen 1988), an item in Sesamstraat. Source: original artwork, photographed at the Netherlands Institute for Sound and Vision.

leaders in stop motion emerge such as Bibelebons (AVRO, 1972-1975) by Johan Volkerijk and De Holle Bolle Boom (AVRO, 1975-1978): the follow up to Bibelebons. Arie Teunissen also made animated leaders: for Kijk naar je Eige (VARA, 1972) and Mijn Idee (NCRV, 1974). The introduction of video made it possible for the graphic designers to make animations themselves. ${ }^{71}$ Johan Volkerijk mentions that with illustration as well as animation, they had to do everything by themselves, including 'spotting' the music: timing the movements of the animation to the music. ${ }^{72}$ They divided the scripts they received into scenes, decided on the amount of drawings, made storyboards, decided how the camera should move over the drawings, and how many seconds are required for each shot. When the operator agreed that it was possible to record the item in four hours, the illustrators started to make the 
drawings, as recording was very expensive.$^{73}$ Later, in the 1980s, the illustrators describe how their work became even more technical, which meant that they felt their work had shifted from illustration to television design. ${ }^{74}$ The first animated items found are made by Teunissen for De Film van Ome Willem (VARA, 1974-1989). For an item called Langzaam en snel (slow and fast), he animates a snail moving across a road. In the meantime, a pedestrian and a cyclist go by, but the snail travels so slowly that the flowers start to bloom in the time he takes to cross the frame. ${ }^{75}$ Animation usually consists of 24 frames per second, but the illustrators of the NOS Design department used 12 frames per second to save time and money, without taking too much of the fluency of the movements away. ${ }^{76}$

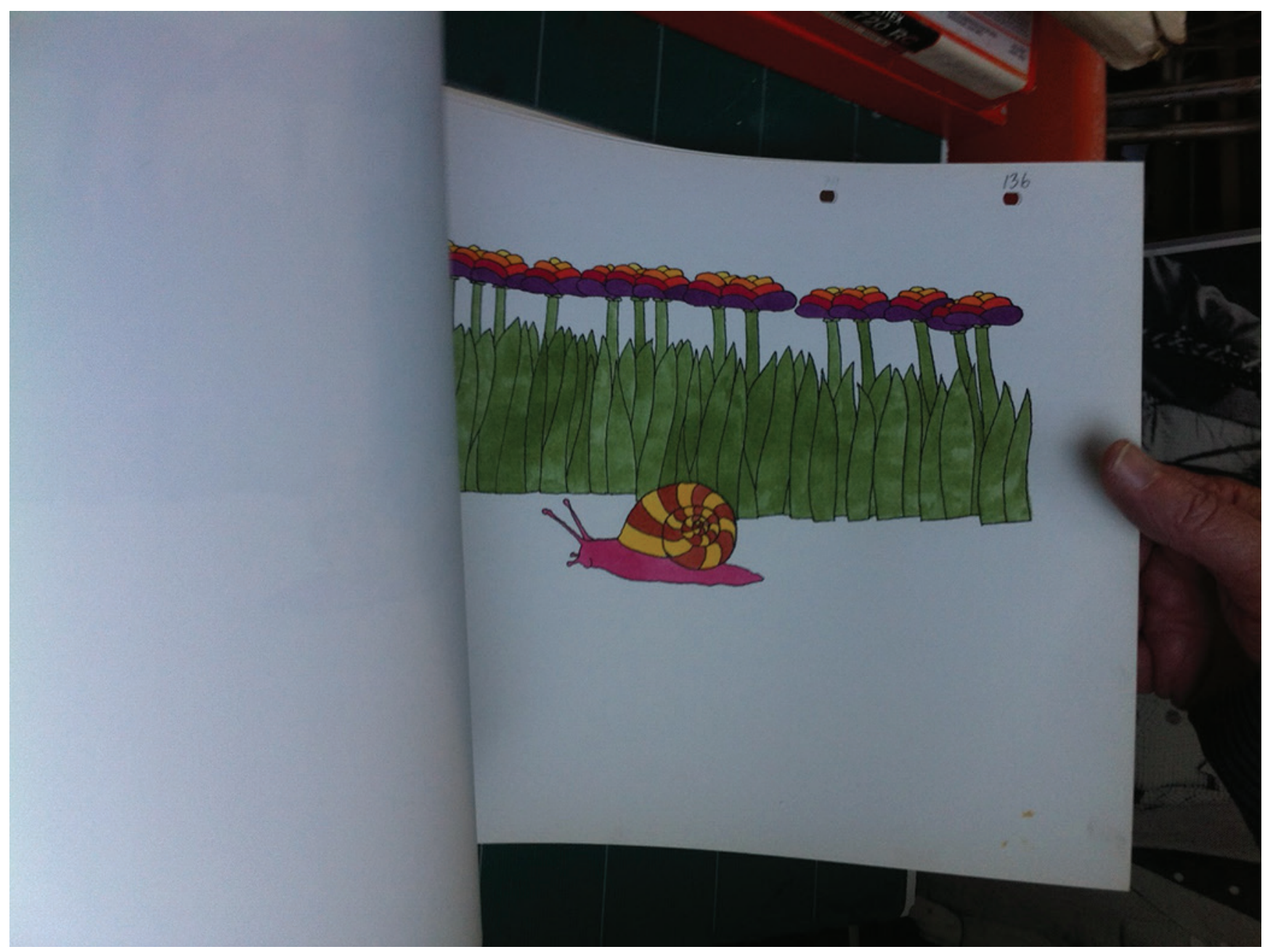

Figure 9. Animation drawings for De Film van Ome Willem (Arie Teunissen VARA 1974-1989). Source: original artwork, photographed at the house of Arie Teunissen. 
In that same year, 1974, there was a sudden explosion of good, creative programmes for children, with programmes such as In de Soete Suikerbol (NCRV, 1975, WG van de Hulst), De Film van Ome Willem and Open en Bloot (VARA, 1974, Hans de Cocq). In addition, the graphic designers were featured in Beeldje voor Beeldje, the exhibition on Dutch animated film in the Stedelijk Museum in Amsterdam. For the first time, it was not the original drawings and designs that were exhibited but the animations themselves. They were shown in sequence, and among them were leaders by Arie Teunissen and Johan Volkerijk, and leaders by designers specialised in graphic design at the NOS. From Hans de Cocq, it was not a leader shown at the exhibition but an animated item made for Open en Bloot: the first Dutch programme about sexual education. The items by de Cocq illustrated the more complex or delicate subjects and were made on cell: they had an illustration as the basis, layered with transparent sheets called 'cells' on which the movable parts were drawn. These cells were continuously replaced under the camera to create a stop-motion. This way, most parts of the animation stay the same while some elements move. The very few fully animated series made in this

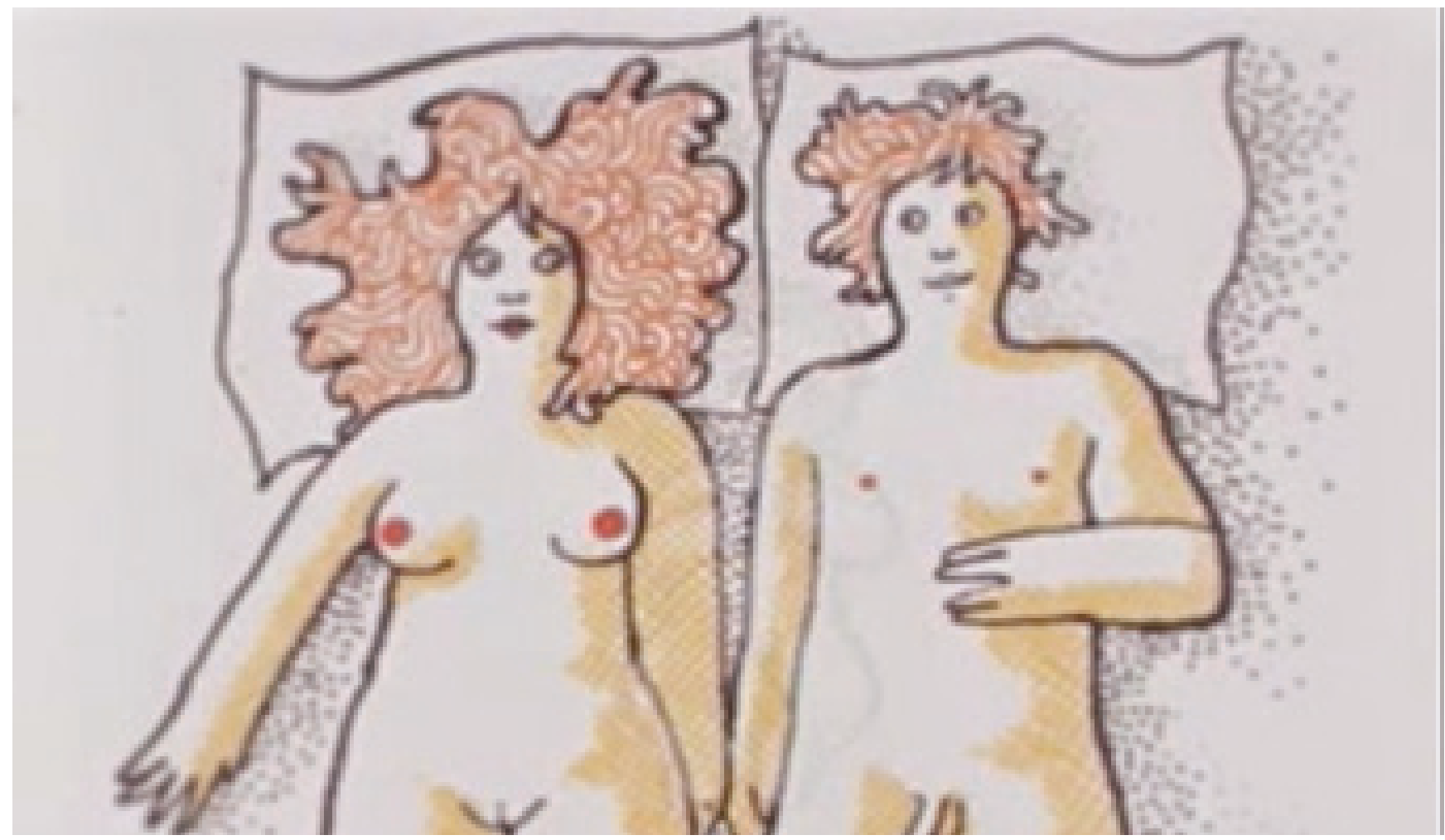


period were quite successful: in 1977 the Dutch television series Barbapapa won a Gold Medal at the International Film Festival in New York, and in 1979, another Dutch series, Doctor Snuggles, received a Silver Medal at the same festival in the category television series for children. ${ }^{77}$ These two series were made externally: the NOS had no hand in their making.

In the 1980s, the possibilities for graphic design were ever growing, and the demand was high: there was an increase in demand for graphic designs for instructive programmes such as infographics, and research was conducted to determine if computers were needed to aid the graphic designers in their work. ${ }^{78}$ The fact that children's programmes now constituted approximately $10 \%$ of the total airing time (compared to approximately $7 \%$ in the 1960 s and 1970 s) also helped. ${ }^{79}$ A striking difference between the 1980s and, for instance, the 1960s, is that in the former decade there were many more television series for children, instead of one-episode programmes. Often, these series were live action programmes with additional illustrated or animated items, which were almost exclusively made by the NOS animators. There are a few exceptions: for instance De Dames, an animation collective consisting of José Vonk, Ellen Meske and Helga Kos, made animations for several Teleac programmes, among which were Open School (1977) and Klusjes in huis (1978), and Insekten for STV in $1982 .{ }^{80}$ However, this remained very rare.

In 1986, the Media Law was drawn up, which was then implemented in $1988 .{ }^{81}$ This law stated that the facility component of the NOS would become an independent company called Nederlands Omroepproductie Bedrijf N.V. (NOB). ${ }^{82}$ This company would now manage and use the studios, cameras, machinery and other facilities but also the graphic design department. They would become independent, which meant that they were allowed to find other clients as well, but the broadcast stations were also able to find other companies to facilitate their programmes. ${ }^{83}$ The NOS continued their technical innovation: a Quantel Paintbox was bought for the department for instance, and Arie Teunissen, who liked trying out new techniques, made digital illustrations on this machine for, among others, Sesamstraat, among which was the item De koning die twee hoofden had. ${ }^{84}$ However, much would change for the graphic department over the following years: in the early 1990s, most of the illustrators, who had enjoyed a whole career at the NTS/NOS, received early retirement and the illustrative department of the Graphic Design division ceased to exist. ${ }^{85}$ Whereas the illustrators flourished from the second half of the 1970s to the end of the 1980s, their work suddenly came to a halt in the first half of the 1990s. The privatisation, however, led to a new phenomenon in animated Dutch television: in 1989, one of the most popular Dutch television programmes and one of the few 
fully traditionally animated ones, was aired: Alfred Jodocus Kwak (VARA, 1989-1991). This series was a story by musician and theatre maker Herman van Veen about a duck called Alfred who travels the world and solves all kinds of political injustices. The production is not entirely Dutch: the drawings that led to the famous character design of Alfred were done by the German Harald Siepermann, and the animation work was done in Japan, the latter to reduce costs. However, as the series was initiated in The Netherlands, this can still be called a Dutch production. In addition, at the end of the 1980s, the computer gave a new impetus to Dutch animation by providing a new method of making animation, with a whole different aesthetic and new possibilities. These changes led to highly creative animations by a whole new generation of animators, its full potential being in the 1990s. Just as the individualists had taken over the studio period in film animation in 1970, a new generation was now taking over the 'studio period' of the NTS/NOS and was ready to make new animations for Dutch television.

The programmes that were illustrated and animated by employees of the NTS/NOS had Dutch television as their main distribution channel of course and, as these makers had a steady income, they did not need to produce work outside television. Therefore, the programmes they made for television were very seldom distributed elsewhere. There are some instances however, where their work was distributed further afield. There were several exhibitions of 'tv-graphics' including illustrations in the 1960s, and the Graphic Design department was featured in the exhibition Beeldje voor Beeldje at the Stedelijk Museum in 1974. Illustrators also mention how their work was occasionally featured and awarded at international animation festivals. ${ }^{86}$ However, as the work of these animators had already reached the target public, and they received a steady income, there was no need to reach further afield, and these exhibitions and screenings remained incidental.

\section{Film and television animation: two separate but unusual journeys}

It could be argued that the Netherlands had two parallel animation scenes between 1970-1989, both of which came to fruition in the 1970s and 1980s: film and television. Some exceptions, such as the work by collective De Dames aside, these two animation traditions did not overlap. The underlying reasons for this are the differences in government support and the widespread belief among the Dutch public that animation is solely produced for children.

The first distribution channel, the Dutch cinemas, had no need for animations from Dutch soil, as they already had sufficient Disney cartoons to screen before the main film. Furthermore, they did 


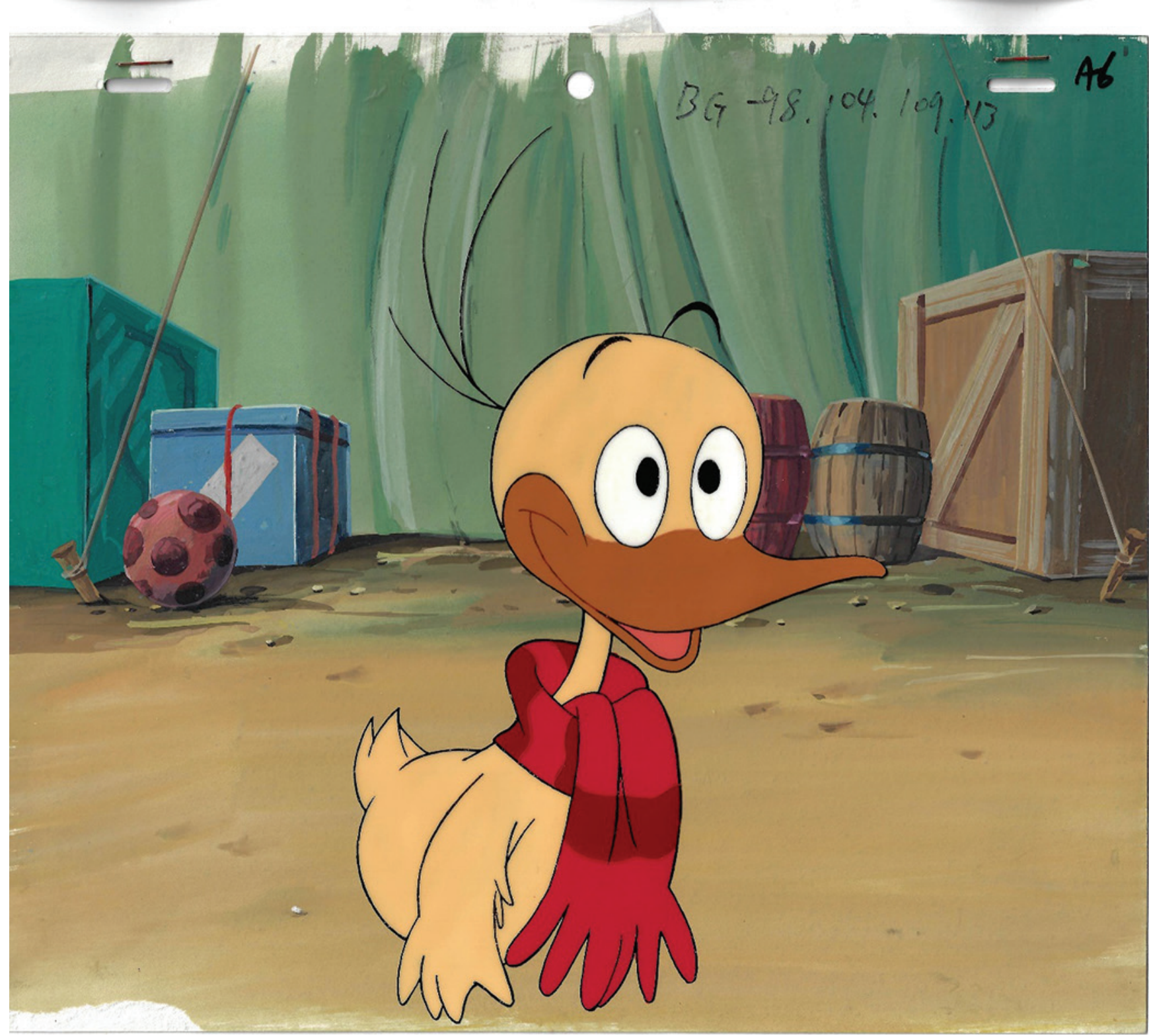

Figure 11. Original drawing for Alfred Jodocus Kwak (Creation Herman van Veen VARA 1989-1991). Source: original artwork, official website of Herman van Veen (https://hermanvanveen.com/product/originele-tekening-alfred-j-kwak-14/).

not know what to do with animations for adults; both film- and television animation were very rarely screened in cinemas.

Television directors, representing the second distribution channel, never asked animators such as Paul Driessen and Børge Ring to make animations for Dutch television because there were already enough in-house animators. The independent work that film animators made varied too much in 
length to be structurally distributed through Dutch television, and, just like cinema, television directors were unaware of how to programme animation for adults. For their part, the television animators never needed to reach beyond television, as their work was shown to a large public and they received a solid income for their work.

The $16 \mathrm{~mm}$ circuit in The Netherlands, as the third distribution channel, was more lucrative, but only for the film animators, and this would always remain a very small circuit.

The lack of financial support by the Dutch government pushed the film animators abroad, whereas the television animators remained in a stable position. At the international festivals, the Dutch animations received recognition and were further distributed throughout many countries, where they finally received a larger audience. This international success brought the animations back to The Netherlands, where they were featured in exhibitions in museums, and a larger interested public was introduced to these animators and their work. It is at the exhibition Beeldje voor Beeldje in 1974 that film animation and tv animation were first shown side-by-side to the same Dutch public.

There have been many changes following the period of 1970-1989. To name but a few: the NOS was privatised and became the commercial NOB, enabling a new generation of animators to pitch their work to broadcasting associations. The computer changed the field of animation in both television and film, adding a new 'toolbox' for creating new types of animation in very different styles than before. In addition, the Internet emerged as a new and vast distribution channel, able to distribute animations across the globe. Furthermore, the idea that animation is only for children has finally changed, as highly popular American television series such as The Simpsons, Southpark and Family Guy have illustrated. It would be interesting to dive further into the impact all these changes have had on the development of animation in the Netherlands, but what is clear is that there is now more overlap between film animation and television animation. This makes the period between 1970-1989, in which Dutch film and television animation are two separate traditions with hardly any overlap, a unique one.

\section{Notes}

1 Jan-Willem de Vries, De Toonder Animatiefilms (Silvester, Den Bosch, 2012), 118.

2 Geoffrey Nowell-Smith, The Oxford History of World Cinema (Oxford, Oxford University Press, 1996), 6-18. 
3 Maureen Furniss, The Animation Bible: A Practical Guide to the Art of Animating from Flipbooks to Flash (New York, Abrams, 2008), 126-127.

4 Tjitte de Vries, “Tien jaar Holland Animation” in Holland Animation Bulletin (Haarlem, Vereniging Holland Animation, 1983), 13.

5 Mette Peters, "Het animatie maakproces in het archief: De vroegste Nederlandse animatiefilms" in TMG Journal for Media History 15, no.1 (2012): 103, doi.org/10.18146/tmg.417.

6 Ton Gloudemans, "Animatiefilm in Nederland" in Jaarboek Mediageschiedenis 3 (Amsterdam, Stichting Beheer IISG, 1991), 135.

7 Peters, “Animatie maakproces in archief," 104-105.

8 Gloudemans, “Animatiefilm Nederland,” 138.

9 Peters, “Animatie maakproces in archief," 105-106.

10 Gloudemans, “Animatiefilm Nederland,” 138-142.

11 Tjitte de Vries, Ati Mul, “Joop Geesink: Poppenfilmproducent,” in Animatie 1 (Rotterdam, Kersten Realisaties, 1984), 13-15.

12 Gloudemans, “Animatiefilm Nederland," 146-148.

13 De Vries, Mul, “Joop Geesink,” 31.

14 Gloudemans, “Animatiefilm Nederland," 149.

15 Jansen, “Good Looser," 22.

16 Gloudemans, “Animatiefilm Nederland," 144.

17 Pim Oosterheert, Bommellexicon: van Aamnaak tot Zwirkvlaai (Maarssen, Cliché, 2005), 13.

18 De Vries, Tien jaar Holland Animation, 19.

19 De Vries, De Toonder Animatiefilms, 306.

20 Ibid., Included DVD.

21 Ibid., 306-315.

22 Ibid., 306-315.

23 De Vries, Tien jaar Holland Animation, 7.

24 Gloudemans, “Animatiefilm Nederland,” 152-153.

25 Karel Dibbets, "Het taboe van de Nederlandse filmcultuur: Neutraal in een verzuild land” in TMG Journal for Media History, 21, nr.1 (2006): 136, doi.org/10.18146/2213-7653.2018.346 .

26 De Vries, Tien jaar Holland Animation, 23. 
27 Nico Crama, "Distributie van Animatiefilm” in Holland Animation Bulletin (Haarlem, Vereniging Holland Animation, 1983), 18.

28 Nico Crama, “Distributie van Animatiefilm,” 16.

29 De Vries, “Tien jaar Holland Animation,” 11.

30 Crama, “Distributie van Animatiefilm,” 18-19.

31 De Vries, “Tien jaar Holland Animation,” 9.

32 Gloudemans, “Animatiefilm Nederland,” 157.

33 De Vries, “Tien jaar Holland Animation,” 9, 26.

34 Ibid., 13.

35 Gloudemans “Animatiefilm Nederland,” 158.

36 Vries, Tien jaar Holland Animation, 21.

37 Piet Kroon, "Reflections in the Window on the World: Dutch Animation of the Eighties" in Holland Animation Bulletin (Haarlem, Vereniging Holland Animation, 1987), 1.

Gloudemans, “Animatiefilm Nederland,” 153.

39 Vries, Tien jaar Holland Animation, 7.

40 Ibid., 3.

41 Crama, "Distributie van Animatiefilm," 16-17.

42 Ibid., 19-20.

43 Ibid., 20-23.

44 De Vries, “Tien jaar Holland Animation,” 6.

45 Gloudemans "Animatiefilm Nederland," 157.

46 Crama, “Distributie van Animatiefilm," 24.

47 Gloudemans, “Animatiefilm Nederland," 157.

48 Film: Orgaan van de Nederlandse Bioscoopbond (18-1-1980), 7.

49 Film: Orgaan van de Nederlandse Bioscoopbond (21-7-1977), 5.

50 Film: Orgaan van de Nederlandse Bioscoopbond (1-9-1982), 5.

51 See for instance Film: Orgaan van de Nederlandse Bioscoopbond (9-6-1977), 12 or Film: Orgaan van de Nederlandse Bioscoopbond (23-10-1981), 9.

52 Ibid., 8-10.

53 Film: Orgaan van de Nederlandse Bioscoopbond (1-12-1974), 15. 
54 “Filmbekroningen," 5.

55 Film: Orgaan van de Nederlandse Bioscoopbond (1-2-1983), 15.

56 Film: Orgaan van de Nederlandse Bioscoopbond (1-3-1989), 13.

57 Annual report NTS (1953-1954), 19-20, Annual report NTS (1968-1969), 15-16

58 Grietje Hoogland, Liegbeesten en Apekoppen (Bachelorscriptie, VU, 2010), 13, 34.

59 Lecture by Jop Euwijk at Sound and Vision on 14th April 2010.

60 Jop Euwijk, "Uitbundige virtuoos met eeuwig heimwee" in Elsevier: Eppo Doeve (Amsterdam, Reed Business Media, 2013), 16.

61 Karel Eykman, Woord voor Woord (Zomer \& Keuning, Utrecht, 1984).

62 Rolf Mager, “TV-Grafiek,” Ariadne (1-4-1967), 437-439.

63 Annual report NTS (1968-1969), 9.

64 Annual report NOS (1971), 82.

65 Hoogland, Liegbeesten en apekoppen, 30.

66 Ibid., 28, 34.

67 Ibid., 31, 35, 37.

68 Annual report NOS (1975), 46.

69 Roy van Vilsteren, Liselotte Doeswijk, Vorm van Vermaak: 60 jaar televisievormgeving in Nederland (Amsterdam, LJ Veen, 2011), 183.

70 Hoogland, Liegbeesten en apekoppen, 29, 35.

71 Ibid., 34.

72 Ibid., 31.

73 Ibid., 24-25.

74 Ibid., 36.

75 Conversation with Arie Teunissen on 21-02-2016.

76 Ibid., 21-02-2016.

77 Film: Orgaan van de Nederlandse Bioscoopbond (24-11-1977), 11, Film: Orgaan van de Nederlandse Bioscoopbond (30-11-1979), 7.

78 Annual report NOS (1981), 47.

79 Annual report NOS (1986), 38. During the 1950s to 1970s, the airing time for children's programmes was usually approximately $7 \%$. 
80 Wim van der Plas, "Computer Animation in Holland” in Holland Animation Bulletin (Haarlem, Vereniging Holland Animation, 1987), 42.

81 Annual report NOS (1986), 3.

82 Annual report NOS (1986), 5.

83 Annual report NOS (1986), 46-47.

84 Vilsteren et. al, Vorm van Vermaak, 251.

85 Annual report NOS (1987), 7.

86 Hoogland, Liegbeesten en apekoppen, 36.

\section{Biography}

Grietje Hoogland is a Ph.D. Student at the University of Amsterdam. She is working on her dissertation 'Illustration and Animation in Dutch Public Youth Television, 1951-1996: Media Technological, Financial and Cultural Influences Forming a Professional Cultural Field', on the development from illustration to animation in Dutch children's television.

TMG Journal for Media History

Volume 23 No $(1 / 2) / 2020$

DOI

https://doi.org/10.18146/tmg.587

\section{PUBLISHER}

Netherlands Institute for Sound and Vision

\section{COPYRIGHT}

Each article is copyrighted (c) by its author(s) and is published under license from the author(s). When a paper is accepted for publication, authors will be requested to agree with the Creative Commons Attribution 4.0 International License. 